\title{
216 慢性副鼻腔炎における嗅覚障害の治療成績一続報一
}

寺口奏子、張田雅之、能田拓也、山田健太郎、山本純平、志賀英明、三輪高喜

金沢医科大学 医学部 耳鼻咽喉科

【はじめに】昨年の本学会で、好酸球性・非好酸球性副鼻腔炎の嗅覚障害改善度について、手術例に加え、非手術例も含 めた治療成績を報告した。今回対象症例数と観察期間を拡大延長し、JESREC stadyの重症度も加味し、嗅覚治療成績を検 討した。【対象と方法】対象は2009年 6 月から 2014 年 9 月までに保存的加療を行った症例と、保存的治療に抵抗し当科で内 視鏡手術を施行した慢性副鼻腔炎症例のうち、治療前後に嗅覚検査等の評価を行い得た症例である。好酸球性副鼻腔診断基 準に基づき、好酸球性と非好酸球性に分類した。【結果】重症例では上気道炎に伴い増悪寛解を繰り返した。また嗅覚改善 率も悪い傾向にあった。また多変量解析により嗅覚改善率に影響を与える因子として、罹病期間とアリナミンテスト陽性が 挙げられた。【考察】今回の検討において、好酸球性副鼻腔炎による嗅覚障害の予後は、重症度により差異はないが、再発 には影響があった。

\section{7 浸潤型副鼻腔真菌症の 1 例}

○植木雄司、今野昭義、間多祐輔 総合南東北病院

今回われわれは比較的まれな浸潤型副鼻腔真菌症の 1 例を経験したので報告する。症例は 72 歳女性で、肺非定型抗酸菌症 治療継続中であった。2012年12月に ESS を施行し左穊骨洞、上顎洞病変を清掃した。手術所見ではアスペルギルス真菌塊 が上顎洞内にみられ、寄生型副鼻腔真菌症と診断した。しかし、2013年 7 月下旬に左眼の視力低下があり再来、CT、MRI では広範な骨破壊とともに、翼口蓋窩、眼窩先端部への病変の進展が認められた。浸潤型副鼻腔真菌症と診断し、手術と抗 真菌薬の投与を行い、視力の回復は得られなかったが治癒することができた。初回手術の診断を再検討するため、初回手術 前の CT、MRI を再評価したところ、微細な変化ではあるが副鼻腔外組織に炎症所見を認め、初回手術時にすでに浸潤型副 鼻腔真菌症であったと考えられた。副鼻腔真菌症のほとんどが寄生型であるが、骨破壊を伴わない初期の浸潤型病変が潜ん でいることを念頭におくべきであると今回の経験から反省させられた。

\section{Maxillary sinus atelectasis の病期進行を経時的に観察できた 1 症例}

\author{
○堀切教平、菊田 周、坂本幸士、籠谷領二、安原一夫、西嶌大宣、齊藤祐毅、平野真希子、近藤健二、 \\ 山岨達也 \\ 東京大学 医学部 耳鼻咽䚐科
}

Maxillary sinus atelectasis(MSA) は持続する上顎洞内の陰圧によって、次第に上顎洞の壁構築が破壊され、さまざまな 臨床症状を呈するまれな疾患である。MSAの進展に陰圧以外のどのような因子がかかわるのか、あるいは骨変形から自覚 症状出現までにどのくらいの期間を要するかなど、病態生理を解明する上で未知の部分も多い。今回、病期進行の経時変化 を画像で観察できた MSA 症例を経験した。症例は東欧出身の39歳女性で、2 年前の頭部 MRI で偶然に上顎洞内側壁の外 側変位を認め、その頃から度重なる副鼻腔炎症状を自覚していた。その後、突然発症の複視と右頬部痛を自覚し当院を受診 した。右上眼瞼部の陥凹、右上方視で複視を認め、画像上、右中鼻道の拡大、右上顎洞内の狭小化と軟部組織陰影、右眼球 低位を認めた。MSAの診断で陰圧解除目的に上顎洞開放術を施行し、自覚症状と骨変形は改善した。MSAの経時変化を同 一症例で今回初めて観察できた。MSAの進行は数年とこれまで想定されたより早く、病期進行には上顎洞内の持続炎症が 関与している可能性が示唆された。

\section{9 鼻中隔 lipomatous hamartoma の 1 例}

\author{
$\bigcirc$ 積山幸祐 ${ }^{1)}$ 、黑野祐一 ${ }^{2}$ \\ 鹿児島生協病院 耳鼻咽喉科 ${ }^{12}$ 、鹿児島大学大学院医歯学総合研究科 耳鼻咽喉科頭頸部外科 ${ }^{2)}$
}

過誤腫（hamartoma）は、ある組織に固有の組織成分が過剩に発育した腫瘍様の病変である。脂肪組織、血管、粘液腺、 平滑筋などで構成されており、組織成分によって lipomatous hamartoma、myoepithelial hamartoma、 leiomyomatous hamartoma な゙の組織学的診断がつけられている。肝、脾、腎、肺などの実質臓器にはしばしばみられるが、鼻腔発生の lipomatous hamartoma は極めてまれである。症例は11歳の女児で鼻閉、鼻痛を主訴に当院を受診した。右鼻腔に発赤した腫瘤を 認め、CT、MRIでは鼻中隔前方に広基性基部を持ち、脂肪成分と同程度の吸収值を示す $3 \mathrm{~cm}$ 弱の腫瘤を認めた。生検した が確定診断には至らなかった。そこで全身麻酔にて鼻腔腫瘍摘出術を施行した。摘出病変の大部分は成熟脂肪細胞からな り、一部では脂肪組織内に鼻腺が介在しており病理組織学的に lipomatous hamartoma と診断された。若干の文献的考察を 加え報告する。 